\title{
Applied Mathematical Model for Construction Planning in a Housing Development Project
}

\section{Grit Ngowtanasuwan}

\author{
Faculty of Architecture, Urban and Creative Arts, \\ Mahasarakham University, Mahasarakham 44150, Thailand \\ grit_n@gmail.com
}

\begin{abstract}
The paper presented a method for solving a construction planning problem in a housing development project using a mathematical model which is an integer linear programming for dividing house construction jobs to three contractors in a project case study. 169 units of the houses in the project would be constructed by the three contractors in two methods, conventional construction method and precast method. The results found a minimum construction cost of the project was 417.69 million baht M\$13.92), and within the total project duration of 72 months. Conclusions and recommendations were discussed in this article
\end{abstract}

Keywords: Housing Development Project, Mathematical Model, Precast Concrete Construction

eISSN 2398-4295 @ 2018. The Authors. Published for AMER ABRA cE-Bs by e-International Publishing House, Ltd., UK. This is an open-access article under the CC BY-NC-ND license (http://creativecommons.org/licenses/bync-nd/4.0/). Peer-review under responsibility of AMER (Association of Malaysian Environment-Behaviour Researchers), ABRA (Association of Behavioural Researchers on Asians) and cE-Bs (Centre for EnvironmentBehaviour Studies), Faculty of Architecture, Planning \& Surveying, Universiti Teknologi MARA, Malaysia.

DOI: http://dx.doi.org/10.21834/ajbes.v3i13.140 


\subsection{Introduction}

Housing development business is a high competition business in Thai construction industry. In Thailand, the business has been allocated in many big cities. Employing a contractor is a conventional method in housing development projects. To gain a competitive advantage in the business, precast construction method has been used for faster in construction time with higher construction cost comparing to conventional construction method. Construction cost for the precast method is higher than a conventional (traditional cast-in-place) construction method. Because they have to provide a cost or budget for a casting factory, facilities, mobile crane for the precast erections and so on. The cost for the precast method might be increased $20-30 \%$, with reducing $40-50 \%$ of construction time comparing to the same building constructed by the conventional method. This issue leads to a question that what is the advantage of between using the precast construction method and the conventional construction method in the housing development business (Grit, 2013).

The purpose of this article presented a method for solving construction planning problem in a housing development project using a mathematical model which is integer linear programming for dividing house construction jobs to contractors in the housing development project. Outputs of the model were to find out a minimum construction cost for all houses in the project within constraints such as total numbers of the house in the project, total project duration, costs-times-methods for each house construction, numbers of the contractor and construction team of the contractors in the project.

\subsection{Research Objectives}

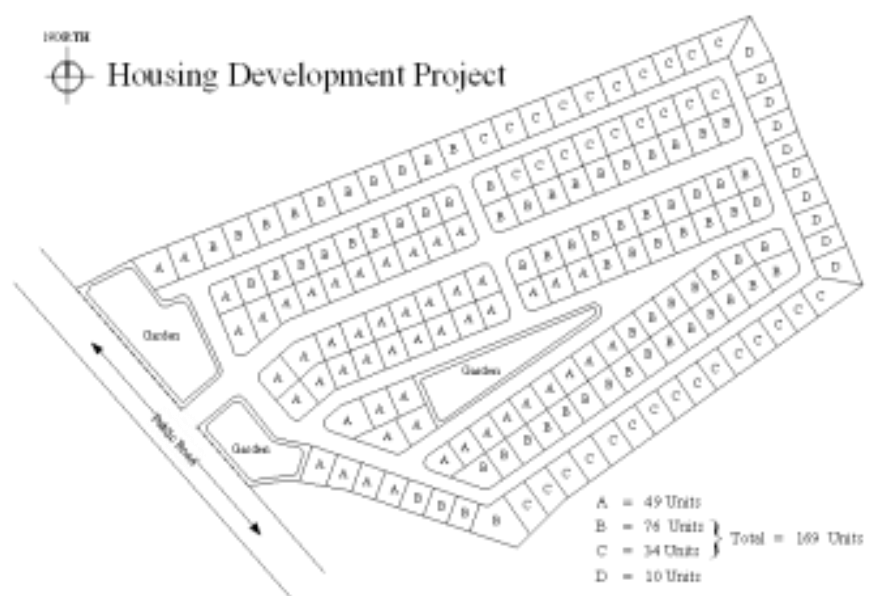

Figure 1: Plan of the housing development project 
- To formulate mathematical models for analysis in dividing house construction jobs to contractors in a housing development project case study.

- To calculate and find out numbers of the house construction jobs for the contractors which has a minimum construction cost of the project

\subsection{Scope of Study}

The scope of this research covered analysis of a housing development project. The total project duration was 72 mounts in construction. The project comprised of four types of single house, type $A=49$ units, Type $B=76$ units, type $C=34$ units and type $D=10$ units, total 169 units in the project as shown in Figure 1. There were three contractors in the project, the contractor ${ }_{1}$ had four construction teams, contractor 2 had five construction teams, and contractor 3 had four construction teams respectively. There were two construction methods in the project, first method was Conventional construction method (traditional cast-in-place) and the second was precast construction method. Construction costs and times for each type of house were different, depended on the capacity of each contractor and the construction methods.

\section{0 Literature Review}

In the Wiki-Based Encyclopedia (2013) recorded "Housing developments" are structured building development of residential properties. "Real Estate" is property consisting of land and the buildings on it, along with its natural resources such as crops, minerals, or water. Real estate development, or property development, is a multifaceted business, encompassing activities that range from the renovation and re-lease of existing buildings to the purchase of raw land and the sale of improved land or parcels to others. Developers are the coordinators of the activities, converting ideas on paper into real property. Real estate development is different from construction, although many developers also construct (Wiki, 2013). Most real estate problems require the allocation of scarce resources to a different type of use so that investors can achieve the maximum profit.

Frederick and Jonathan (2001) stated that construction under the traditional construction procedure is performed by contractors. While they would like to satisfy the owner and the building designers, contractors have the main objective of making a profit. Hence, their initial task is to prepare a bid price based on an accurate estimate of construction costs. This requires the development of a concept for the performance of the work and a construction time schedule. After a contract has been awarded, contractors must furnish and pay for all materials, equipment, power, labor, and supervision required for construction. The owner compensates the contractors for construction costs and services. 
Kim (2002) stated "Precast Concrete" is concrete which has been prepared for casting, cast and cured in a location which is not its final destination. Precast concrete involves a mould shaped to the required form, in which reinforcement is placed, and concrete is then cast. The essential feature is that the same mould is used many times, without any modification. Such casting is done either in a factory or at a fixed location on the site. The completed precast concrete elements are finally transported to the erection area (Haas A. M, 1983). Precast concrete has been used for many decades in the construction industry. Its full potential in terms of economy, versatility, appearance, structural strength, quality, and permanence continues to expand as witnessed by the new projects all over the continent ( $\mathrm{PCl}, 1973$ ). Nowadays, construction by the precast concrete method has been generally used in residential buildings, office buildings, apartments, or other low-rise buildings. However, the construction cost for the precast method is higher than a conventional (traditional cast-in-place) construction method. Because they have to provide a cost for casting factory, facilities, mobile crane for erections and so on. The cost for the precast method might be increased $20-30 \%$, with reducing $40-50 \%$ of construction time comparing to a same building by the conventional method.

"Prefabrication" often associated with the terms offsite assembly or just simply. It is then the parts that have been produced and then are assembled on site. Prefabrication in building construction is the process of building in a factory, implies a mass-production model. Prefabrication involves not only the design of a beautiful product, with detailed connections, interlacing materials that come together in either standardized or unique ways, but also has to be designed from a production standpoint. Architects are not generally proficient at the product and production design and are not trained to be industrialists (Ryan, 2010).

"Linear programming" is a mathematical modeling technique designed to optimize the usage of limited resources. Successful applications of linear programming exist in the areas of military, industry, agriculture, transportation, economics, health systems, and even behavioral and social sciences (Taha, 1997). Hillier and Lieberman (1990) stated that linear programming uses a mathematical model to describe the problem of concern. "Integer linear programming" is a linear programming in which some or all the variables are restricted to integer values. The linear programming model, which consists of the objective and constraint functions, could be solved by computer software which can solve mixed integer and linear programming model.

Grit (2013) presented a research related to an application of the mathematical model for construction in a housing development project. The objective function of the model was to minimize the total construction cost of the project case study. The results showed the application of the mathematical model was applicable effectively. The output of the model was a minimum construction cost of the project. 
Fatma (2012) published a paper, a multi-objective optimization model for scheduling linear construction projects. Linear construction projects have many identical units wherein activities repeat from one unit to another. The model enables construction planners to generate optimal / near-optimal construction plans that minimize project duration, total work interruptions, and the total number of crews. An application example is analyzed to illustrate the use of the model and demonstrate its capabilities in optimizing the scheduling of linear construction projects. The results of the optimization conducted prove the robustness and consistency.

Connie et al. (2001) published a research related to the application of linear programming for dormitory development plan at Petra Christian University. In the research, the linear programming technique has been used to calculate the number of rooms and area of each facility which could satisfy the constraints and to obtain optimum profit. A number of bedrooms, the number of bathrooms and area of each facility such as living room, dining room, common room, cafeteria, bookshop, mini market, phone booths, sports facilities, and parking space are recommended. Since the investment is financially feasible, the dormitory could be built in the future. The linear programming can be utilized as a useful tool for decision making to optimize the decision and satisfy the simultaneous constraints.

\subsection{Methodology}

Research methodology in this article was formulating and solving a mathematical method, three parts of the methodology included problem formulation, data collection, and model formulation.

\subsection{Problem Formulation}

Problems were studied and found that the main problem was dividing house construction jobs to the three contractors in the project. Each contractor was different in their construction capacities such as construction teams, construction times and costs for each type of house. The contractors 1, 2, and 3 have four, five, and four construction teams respectively. They could start and construct the houses at the same time as the numbers of their construction teams.

\subsection{Data Collection}

From the studied problem in the problem formulation, data were used in analysis of the problem which researcher took to formulate the mathematical models included:

- Collecting data regarding construction costs for each type of house and construction method.

- Collecting data regarding construction times for each type of house and construction method. 
- Project duration.

The three contractors were requested to submit construction estimations (costs and times) for each type of house and construction method. The collected data was summarized as shown in Table 1.

Table 1: Construction Times and Costs for each Contractor

\begin{tabular}{|c|c|c|c|c|}
\hline Contractor & $\begin{array}{l}\text { House } \\
\text { Type }\end{array}$ & $\begin{array}{l}\text { Construction } \\
\text { Method }\end{array}$ & $\begin{array}{c}\text { Construction Time } \\
\text { (Month/Unit) }\end{array}$ & Construction Cost ( $\mathrm{M}_{\mathrm{B}} /$ Unit) \\
\hline \multirow{8}{*}{$\begin{array}{c}1 \\
\text { (4 Teams) }\end{array}$} & \multirow{2}{*}{ A } & Conventional & 8.4 & 2.42 \\
\hline & & Precast & 4.9 & 3.30 \\
\hline & \multirow{2}{*}{ B } & Conventional & 7.8 & 2.10 \\
\hline & & Precast & 4.4 & 2.83 \\
\hline & \multirow{2}{*}{ C } & Conventional & 7.7 & 1.45 \\
\hline & & Precast & 4.2 & 2.82 \\
\hline & \multirow[b]{2}{*}{$D$} & Conventional & 6.3 & 0.95 \\
\hline & & Precast & 3.2 & 1.55 \\
\hline \multirow{8}{*}{$\begin{array}{c}2 \\
\text { (5 Teams) }\end{array}$} & \multirow[b]{2}{*}{ A } & Conventional & 8.3 & 2.45 \\
\hline & & Precast & 5.1 & 3.25 \\
\hline & \multirow[b]{2}{*}{ B } & Conventional & 7.8 & 2.15 \\
\hline & & Precast & 4.5 & 2.80 \\
\hline & \multirow[b]{2}{*}{ C } & Conventional & 7.5 & 1.40 \\
\hline & & Precast & 4.5 & 2.35 \\
\hline & \multirow{2}{*}{ D } & Conventional & 6.5 & 0.90 \\
\hline & & Precast & 3.5 & 1.60 \\
\hline \multirow{8}{*}{$\begin{array}{c}3 \\
\text { (4 Teams) }\end{array}$} & \multirow[b]{2}{*}{ A } & Conventional & 8.5 & 2.40 \\
\hline & & Precast & 5.0 & 3.20 \\
\hline & \multirow[b]{2}{*}{ B } & Conventional & 8.0 & 2.00 \\
\hline & & Precast & 4.5 & 2.85 \\
\hline & \multirow[b]{2}{*}{ C } & Conventional & 7.0 & 1.50 \\
\hline & & Precast & 4.0 & 2.25 \\
\hline & \multirow[b]{2}{*}{ D } & Conventional & 6.0 & 1.00 \\
\hline & & Precast & 3.0 & 1.50 \\
\hline
\end{tabular}

\subsection{Model Formulation}

Formulating the mathematical models in this research was integer linear programming which comprised of three main parts including:

\subsubsection{Decision Variables}

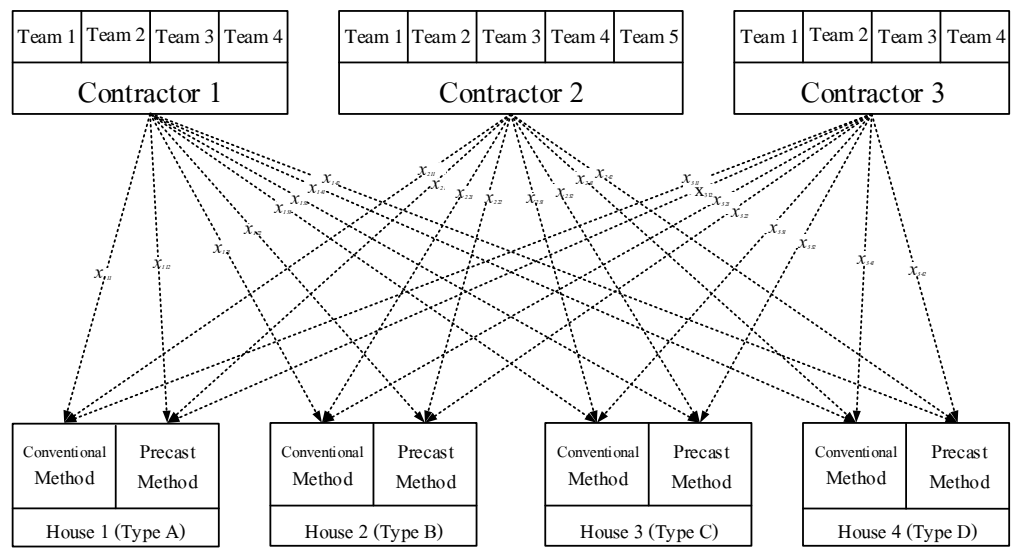

Figure 2: Network Relationships of the Decision Variables 
$X_{\mathrm{jk}}$ was a number of house construction job for the contractor $\mathrm{i}$, house type $\mathrm{j}$, and construction method k. For simple understanding, a network relationship of the decision variables was presented in Figure 2.

\subsubsection{Coefficients of Decision Variables}

$\mathrm{C}_{\mathrm{ijk}}$ was construction cost of the contractor $\mathrm{i}$, house type $\mathrm{j}$, and construction method $\mathrm{k}$ (unit: million baht/unit).

tijk was construction time/number of team of the contractor $\mathrm{i}$, house type $\mathrm{j}$, and construction method k (unit: month).

$\mathrm{i}=1,2,3 \quad \mathrm{j}=1,2,3,4 \quad \mathrm{k}=1,2 \quad$ as shown in Table 2.

\subsubsection{Objective Function}

The objective function in this research was an objective which minimum construction cost of the project. From the collected data, formulating objective function equation was defined as follows:

$$
\operatorname{Min} Z=\sum_{i=1}^{3} \sum_{j=1}^{4} \sum_{k=1}^{2} c_{i j k} x_{i j k}
$$

(1) Expanded to

MIN Cost $=$

$2.42 X_{111}+3.30 X_{112}+2.10 X_{121}+2.83 X_{122}+1.45 X_{131}+2.30 X_{132}+0.95 X_{141}+1.55 X_{142}+2.45 X_{211}+3.25 X_{212}$

$+2.15 \mathrm{X}_{221}+2.80 \mathrm{X}_{222}+1.40 \mathrm{X}_{231}+2.35 \mathrm{X}_{232}+0.90 \mathrm{X}_{241}+1.60 \mathrm{X}_{242}+2.40 \mathrm{X}_{311}+3.20 \mathrm{X}_{312}+2.00 \mathrm{X}_{321}+2.85 \mathrm{X} 3$ $22+1.50 \mathrm{X}_{331}+2.25 \mathrm{X}_{332}+1.00 \mathrm{X}_{341}+1.50 \mathrm{X}_{342}$

\subsubsection{Constraint Functions}

Constraint functions included a number each type of house in the project, and the project duration.

Total house in the project was 169 units:

House 1 (type A), 49 units

(2) Expanded to

$$
\sum_{i=1}^{3} \sum_{k=1}^{2} x_{i 1 k}=49
$$

$$
X_{111}+X_{112}+X_{211}+X_{212}+X_{311}+X_{312}=49
$$

House 2 (type B), 76 units

$$
\sum_{i=1}^{3} \sum_{k=1}^{2} x_{i 2 k}=76
$$


(3) Expanded to

$$
\mathrm{X}_{121}+\mathrm{X}_{122}+\mathrm{X}_{221}+\mathrm{X}_{222}+\mathrm{X}_{321}+\mathrm{X}_{322}=76
$$

House 3 (type C), 34 units

(4) Expanded to

$$
\sum_{i=1}^{3} \sum_{k=1}^{2} x_{i 3 k}=34
$$

$$
X_{131+} X_{132}+X_{231}+X_{232}+X_{331}+X_{332}=34
$$

House 4 (type D), 10 units

(5) Expanded to

$$
\sum_{i=1}^{3} \sum_{k=1}^{2} x_{i 4 k}=10
$$

$$
X_{141+} X_{142+}+X_{241}+X_{242}+X_{341}+X_{342}=10
$$

Project duration must less than or equal to 72 months for all the three contractors: Contractor 1

$$
\sum_{j=1}^{4} \sum_{k=1}^{2} t_{1 j k} x_{1 j k} \leq 72
$$

(6) Expanded to

$$
2.10 X_{111}+1.23 X_{112}+1.95 X_{121}+1.10 X_{122}+1.93 X_{131}+1.05 X_{132}+1.58 X_{141}+0.80 X_{142} \leq 72
$$

Contractor 2

$$
\sum_{j=1}^{4} \sum_{k=1}^{2} t_{2 j k} x_{2 j k} \leq 72
$$

(7) Expanded to

$1.66 \mathrm{X}_{211}+1.02 \mathrm{X}_{212}+1.55 \mathrm{X}_{221}+0.90 \mathrm{X}_{222}+1.50 \mathrm{X}_{231}+0.90 \mathrm{X}_{232}+1.30 \mathrm{X}_{241}+0.70 \mathrm{X}_{242} \leq 72$ Contractor 3

$$
\sum_{j=1}^{4} \sum_{k=1}^{2} t_{3 j k} x_{3 j k} \leq 72
$$

(8) Expanded to

$$
\begin{aligned}
2.13 \mathrm{X}_{311}+1.25 \mathrm{X}_{312}+2.00 \mathrm{X}_{321}+1.13 \mathrm{X}_{322+1.75} \mathrm{X}_{331}+1.00 \mathrm{X}_{332}+1.50 \mathrm{X}_{341+}+0.75 \mathrm{X}_{342} \leq 72 \\
x_{i j k} \geq 0 \text { and Integer }
\end{aligned}
$$


Ngowtanasuwan, G. / Asian Journal of Behavioural Studies (AjBeS), 3(13) Sep / Oct 2018 (p.22-33)

Table 2: Coefficients of the Decision Variables ( $\left.\mathrm{C}_{\mathrm{j} j \mathrm{k}}, \mathrm{t}_{\mathrm{jik}}\right)$

\begin{tabular}{|c|c|c|c|c|c|}
\hline Contractor & $\begin{array}{l}\text { House } \\
\text { Type }\end{array}$ & $\begin{array}{l}\text { Construction } \\
\text { Method }\end{array}$ & $\begin{array}{l}\text { Construction Time } \\
\text { (month/unit) }\end{array}$ & $\begin{array}{c}\text { Construction Cost } \\
\text { (mi/unit), } C_{i j k}\end{array}$ & $\begin{array}{c}\text { Construction Time / } \\
\text { Number of Team } \\
\text { (month/unit), } \mathrm{t}_{\mathrm{ijk}}\end{array}$ \\
\hline \multirow{8}{*}{$\begin{array}{c}1 \\
\text { (4 Teams) }\end{array}$} & \multirow{2}{*}{1} & 1 & 8.40 & 2.42 & 2.10 \\
\hline & & 2 & 4.90 & 3.30 & 1.23 \\
\hline & \multirow{2}{*}{2} & 1 & 7.80 & 2.10 & 1.95 \\
\hline & & 2 & 4.40 & 2.83 & 1.10 \\
\hline & \multirow{2}{*}{3} & 1 & 7.70 & 1.45 & 1.93 \\
\hline & & 2 & 4.20 & 2.30 & 1.05 \\
\hline & \multirow[b]{2}{*}{4} & 1 & 6.30 & 0.95 & 1.58 \\
\hline & & 2 & 3.20 & 1.55 & 0.80 \\
\hline \multirow{8}{*}{$\begin{array}{c}2 \\
\text { (5 Teams) }\end{array}$} & \multirow{2}{*}{1} & 1 & 8.30 & 2.45 & 1.66 \\
\hline & & 2 & 5.10 & 3.25 & 1.02 \\
\hline & \multirow[b]{2}{*}{2} & 1 & 7.75 & 2.15 & 1.55 \\
\hline & & 2 & 4.50 & 2.80 & 0.90 \\
\hline & \multirow{2}{*}{3} & 1 & 7.50 & 1.40 & 1.50 \\
\hline & & 2 & 4.50 & 2.35 & 0.90 \\
\hline & \multirow[b]{2}{*}{4} & 1 & 6.50 & 0.90 & 1.30 \\
\hline & & 2 & 3.50 & 1.60 & 0.70 \\
\hline \multirow{8}{*}{$\begin{array}{c}3 \\
\text { (4 Teams) }\end{array}$} & \multirow{2}{*}{1} & 1 & 8.50 & 2.40 & 2.13 \\
\hline & & 2 & 5.00 & 3.20 & 1.25 \\
\hline & \multirow[b]{2}{*}{2} & 1 & 8.00 & 2.00 & 2.00 \\
\hline & & 2 & 4.50 & 2.85 & 1.13 \\
\hline & \multirow{2}{*}{3} & 1 & 7.00 & 1.50 & 1.75 \\
\hline & & 2 & 4.00 & 2.25 & 1.00 \\
\hline & \multirow[b]{2}{*}{4} & 1 & 6.00 & 1.00 & 1.50 \\
\hline & & 2 & 3.00 & 1.50 & 0.75 \\
\hline
\end{tabular}

\subsection{Results and Discussions}

Tools in this research included a personal computer and integer linear programming software. Data analysis, researcher inputted the data into a personal computer by using an integer linear programming software for the data analysis; the data included equation (1) to (9) from the model formulation. After running the models, the following output had been obtained. The results were shown in Table 3.

Table 3: Results of the data analysis by the integer linear programming software

\begin{tabular}{|c|c|c|c|c|c|c|c|c|c|c|c|c|c|c|c|c|c|c|c|c|c|c|c|c|}
\hline Contractor & \multicolumn{8}{|c|}{1} & \multicolumn{8}{|c|}{2} & \multicolumn{8}{|c|}{3} \\
\hline House & 1 & 1 & 2 & 2 & 3 & 3 & 4 & 4 & 1 & 1 & 2 & 2 & 3 & 3 & 4 & 4 & 1 & 1 & 2 & 2 & 3 & 3 & 4 & 4 \\
\hline $\begin{array}{c}\text { Construction } \\
\text { Method }\end{array}$ & 1 & 2 & 1 & 2 & 1 & 2 & 1 & 2 & 1 & 2 & 1 & 2 & 1 & 2 & 1 & 2 & 1 & 2 & 1 & 2 & 1 & 2 & 1 & 2 \\
\hline $\begin{array}{l}\text { No. of House } \\
\text { (unit), } x_{i j k}\end{array}$ & 22 & 0 & 1 & 20 & 0 & 1 & 0 & 1 & 0 & 0 & 0 & 55 & 15 & 0 & 0 & 0 & 0 & 27 & 0 & 0 & 18 & 0 & 0 & 9 \\
\hline $\begin{array}{l}\text { Project Cost } \\
\text { (million baht) }\end{array}$ & & & & & & & & & & & & 69 & $1 \$ 13$. & & & & & & & & & & & \\
\hline $\begin{array}{l}\text { Project } \\
\text { Duration } \\
\text { (month) }\end{array}$ & & & & & & & & & & & & 7 & & & & & & & & & & & & \\
\hline
\end{tabular}




\subsection{Conclusion}

This article presented a method for solving construction planning problem in the housing development project using a mathematical model which is an integer linear programming for dividing house construction jobs to contractors in the housing development project case study. The output of the model was to find out the minimum construction cost for all houses in the project within constraints such as total numbers of the house in the project, total project duration, costs-times-methods for each house construction, numbers of the contractor and construction team of the contractors in the project.

The results found that application of the mathematical model in the decision was applicable. The mathematical models of the case study were formulated as shown in equation (1) to (9), results shown the minimum construction cost was 417.69 million baht $(M \$ 13.92)$ and the project duration would be finished within 72 months. House construction jobs in the housing development project (total 169 units) were divided and assigned to each contractor as follows:

Contractor 1, 45 units including:

Type A house by conventional construction method 22 units.

Type $B$ house by conventional construction method 1 unit, and precast construction method 20 units.

Type $\mathrm{C}$ house by precast construction method 1 unit.

Type $D$ house by precast construction method 1 unit.

Contractor 2, 70 units including:

Type $B$ house by precast construction method 55 units.

Type $C$ house by conventional construction method 15 units.

Contractor 3, 54 units including:

Type A house by precast construction method 27 units.

Type $C$ house by conventional construction method 18 units.

Type $\mathrm{D}$ house by precast construction method 9 units.

The results have shown the application of the mathematical model which is integer linear programming technique in this research was applicable effectively to the obtained results were the most economical construction cost. By using this model, a construction manager or project owner will be able to choose the best solution based on the construction cost aspect. Recommendations for this research are applications of the mathematical model can be applied to other more complicated problems. Constraint functions can be added more other requirements such as labour constraints, material constraints, quality in constructions or other conditions. Moreover, the objective function can be applied to multi-criteria optimization (more than one objective function) such as minimized construction cost, maximized quality in construction, and minimized project duration. 


\section{Acknowledgement}

This research was supported funding by the research project grant provided by the faculty of Architecture Urban Design and Creative Arts, Mahasarakham University, Thailand.

\section{References}

Connie Susilawati, Desire L. Litaay, and Andre Parsaulian (2001). Application of Linear Programming for Dormitory Development Plan at Petra Christian University, "DimensiTeknikSipil” volume 3 number 2 September 2001 p.59-63.

Fatma A. Agrama. (2012). Multi-objective generic optimization of linear construction projects, “Housing and Building National Research Center, Elsevier.

Frederick S. Merritt and Jonathan T. Ricketts (2001). "Building design and construction handbook" Sixth Edition McGraw-Hill Companies, Inc. New York.

Grit Ngowtanasuwan (2013). Mathematical Model for Optimization of Construction Contracting in Housing Development Project. “Procedia Social and Behavioral Sciences”, AicE-Bs 2013 London, ScienceDirect, Elsevier Ltd.

Haas A. M. (1983). “Precast Concrete: Design and Applications”. Essex. Applied Science Publishers Ltd.

Hillier S. Frederick and Lieberman J. Gerald (1990). “Introduction to Operations Research”, 5th ed. McGraw-Hill Book Co. Singapore. p466.

Kim S. Elliott (2002). “Precast Concrete Structures", 1st published. Oxford. Butterworth-Heinemann Publications. $\mathrm{PCl}$. (1973). “Architectural Precast Concrete”, 1st ed. Prestressed Concrete Institute ( $\mathrm{PCl})$.

Ryan E. Smith (2010). "Prefab Architecture a Guide to Modular Design and Construction”. John Wiley \& Sons, Inc., Hoboken, New Jersey.

Taha A. Hamdy. (1997). “Operations Research an Introduction”. New Jersey. Prentice-Hall International, Inc. p367.

Wiki (2013). “Wiki - Based Encyclopedia”. Available at: http://en.wikipedia.org wiki/housing development, 